\title{
Work Motivation as a Mediating Variable between Human Resources Competence and Organizational Climate against Job Satisfaction at the Yapen Islands Resort Police
}

\author{
Almon Julius Marpaung \\ Faculty of Economics, Universitas Terbuka, Indonesia \\ Email: marpaung170214@gmail.com
}

\begin{abstract}
:
This research was conducted to analyze the influence of HR competence and organizational climate on work motivation, the influence of HR competence, organizational climate, and work motivation on job satisfaction, and work motivation as a mediation for the influence of HR competence and organizational climate on job satisfaction. Descriptive research method with a quantitative approach to causality was used. Simple random sampling technique and Slovin formula were used to determine the number of respondents and obtained 167 respondents. The research instrument was a questionnaire with a 5-point Likert scale. The path analysis method and the Sobel test with the help of SPSS software were used to test the hypothesis. The results of this study indicate that human resource competence and organizational climate have a positive and significant effect on work motivation. Organizational climate and work motivation have a positive and significant effect on job satisfaction, while HR competencies do not have a significant effect on job satisfaction. Then work motivation can mediate the relationship between $H R$ competencies on job satisfaction and the relationship between organizational climate and job satisfaction.
\end{abstract}

Keywords:

HR competence; organizational climate; work motivation, job satisfaction

\section{Introduction}

Polres Yapen Islands is an organization within the district / city that is under the Papua Police. The Yapen Islands Police are in charge of six Polsek, namely South Yapen Police, Port Area Police, Angkaisera Polsek, Yapen Timur Police, Yapen Barat Police, and Pom Polsek. The number of personnel at the Yapen Islands Police is 287 consisting of three personnel with the rank of Pamen (Intermediate Officers), 27 personnel with the rank of Pama (First Officer), and 257 personnel with the rank of NCO. Thus the number of personnel at the Polres Yapen Islands is dominated by personnel with the rank of NCO.

In order to find competent police officers, it starts with a recruitment process that does not tolerate the practice of bribery (Goldsmith, 2005). The recruitment of prospective members must technically meet the requirements, so that the members who later qualify are those who are truly competent. Apart from improving the recruitment system, efforts made to improve the competence of human resources at the Yapen Islands Police are through training. The number of Yapen Islands Police personnel who have attended the training is 45 personnel. This condition shows that there are still a small number of Yapen Islands Police personnel who attend education or training. 
The small number of Yapen Islands Police personnel who attend this education or training is basically not profitable for the police institution, especially the Yapen Islands Police. This is because education or training is one way that can be used to improve HR competencies. The results of the interviews conducted by researchers indicated that the reasons for members not to attend education and training were because they were not ready, it was enough with current conditions, did not need these skills and so on. The impact of the lack of personnel who did not attend this training was the low evaluation score obtained by the Yapen Police. Based on the letter of the Papua Police Chief No B / 2854 / XII / REN.5.1. / 2019ITWASDA shows that the Yapen Islands Police get a score of 64.14 in the CC category.

The phenomenon that researchers encounter in the field, organizational climate in The Yapen Islands Police Station is not yet fully formed. This can be seen from the results of discussions with one of the AIPDA and the observations of researchers who found that there are still some members who do not fully understand their respective duties. This condition causes the sense of responsibility that each member of the organization has not developed properly.

The motivation of the Yapen Islands Police personnel needs to be studied because not all assignments are in accordance with what the personnel want. The results of observations and the results of preliminary discussions indicate that the Yapen Islands Police members prefer to be assigned to the Yapen Selatan Polsek and the Port area Polsek. This is because the location is relatively busy and the distance is close to urban areas. Thus members who happen to work in locations that are less desirable will have low motivation, so that with high HR competence and a conducive organizational climate but not balanced with motivation because they work in locations far from the city, it will make them dissatisfied with their work (Arafat et al., 2012; Rante \& Warokka, 2016).

Based on the problems that have been described and there is still a research gap on the results of research on the influence of HR competence and organizational climate on job satisfaction, the authors are interested in conducting this research. The purpose of this research is to test empirically the effect of HR competence and organizational climate on work motivation, the influence of HR competence and organizational climate on job satisfaction, the effect of work motivation on job satisfaction, and the influence of HR competence and organizational climate on job satisfaction at the Archipelago Police. Yapen which is mediated by work motivation.

\section{Review of Literatures and Hypothesis Development}

\subsection{Job Satisfaction}

Abuhashesh et.al., (2019) defines job satisfaction as a subjective assessment of the individual related to the way a person views their job. Mueller dan Kim (2008) In addition, job satisfaction is a pleasant emotional state that results from the achievement of work values.identify two types of job satisfaction, namely feelings about the job as a whole and feelings about aspects of the job, such as benefits, salaries, positions, career opportunities, work environment, and relationships between employees. According to Masum et al. (2015), job satisfaction is the emotional status and attitude of employees towards their jobs.

\subsection{HR Competencies}

Several previous studies have proven that HR competencies have a positive and 
significant effect on work motivation (Murgianto et al., 2016; Rijanti et al., 2017; Solehudin \& Yusuf, 2018). Competence is very influential on the work motivation of employees so that these competencies need to be improved in order to increase employee motivation (Syamsir, 2020). Employees with good and appropriate competencies will be able to understand their work and functions so that it will foster high motivation for the organization (Murgianto et al., 2016). Based on previous theory and research, the first hypothesis proposed is:

H1: There is a positive and significant influence between HR competencies on work motivation.

Previous research results have also proven that HR competencies have a positive and significant effect on job satisfaction (Dharmanegara et al., 2016; Renyut et al., 2017; Sabuhari et al., 2020; Trivellas et al., 2015). Workers who believe in their ability to do a job will encourage the company to motivate employees to work harder, the reciprocal relationship between employees and the company makes employees satisfied (Berlian, 2018). Employees who show their potential according to their knowledge, skills, experience, mastery of attitudes, expertise and skills can affect the employee's job satisfaction (Saban et al., 2020). Thus the next hypothesis proposed is: satisfaction.

H3: There is a positive and significant influence between HR competencies on job

\subsection{Organizational Climate}

Several previous researchers have proven that there is a positive and significant influence between organizational climate and work motivation (Diputra et al., 2018; Haseeb et al., 2016; Naseer \& Devi, 2019). Research conducted by Haseeb et al. (2016) concluded that the dimensions of organizational climate which include innovation, reward, empowerment, training and development and communication have a positive relationship with employee motivation and conflict has a negative relationship with employee motivation (Haseeb et al., 2016). The better the organizational climate that is created in the company, the more work motivation felt by employees (Diputra et al., 2018). Therefore, the hypothesis proposed is:

H2: There is a positive and significant influence between organizational climate on work motivation

Research conducted by Ahmad et al. (2018) concluded that employees who work in organizations with a more positive climate tend to be more satisfied with their jobs and more committed to the organization. Employees who work in organizations with a more positive climate tend to be more satisfied with their jobs (Morris \& Bloom, 2002). Therefore the next hypothesis is:

H4: There is a positive and significant influence between organizational climate on job satisfaction

\subsection{Components of Classroom Management}

The results of research conducted by Rosalia et al. (2020), Carvalho et al. (2020), Pratomo and Warokka (2013), dan Sohail et al. (2014) prove that there is a positive influence between work motivation and job satisfaction. A person can feel job satisfaction when he has high motivation, skilled, and satisfied workforce (Saleem et al., 2010). Work motivation both internally and externally forces employees to work more enthusiastically which can result in job satisfaction (Sohail et al., 2014). Thus the proposed hypothesis is: 
satisfaction

H5: There is a positive and significant influence between work motivation on job

The results of research conducted by Josephine dan Harjanti (2017) and Hasmiah et al. (2020) prove that work motivation can mediate the relationship between HR competencies and job satisfaction. Other research conducted by Utoyo et al. (2019) shows a positive and significant relationship between competence and employee performance mediated by work motivation. HR competencies as previously mentioned have an important role in creating job satisfaction. However, motivation also has an equally important role in influencing job satisfaction. For this reason, this study seeks to test whether HR competencies can affect job satisfaction through work motivation. Thus the hypothesis proposed in this study are as follows:

H6: Work motivation is able to mediate the relationship between HR competencies and job satisfaction

Research conducted by Saeed dan Nasir (2016) prove that work motivation is able to mediate the relationship between organizational climate and job satisfaction. In addition, research conducted by Gheitani et al. (2019) found that intrinsic motivation can mediate the relationship between Islamic work ethics and job satisfaction. Therefore, this study examines whether the motivation variable can also mediate the relationship between organizational climate and job satisfaction, so that the next hypothesis proposed is:

H7: Work motivation can mediate the relationship between organizational climate and job satisfaction

From the theoretical basis and various results of previous research, the framework proposed in this study are as follows:

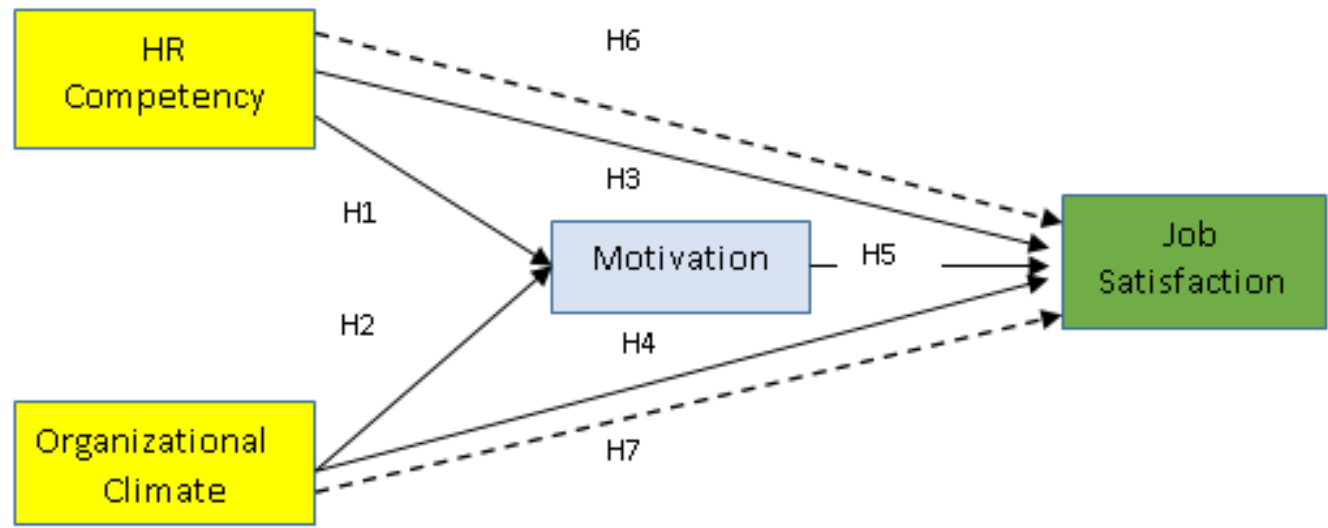

Information

: Direct Influence

: Indirect Effect

Figure 1. Research Model

\section{Research Methods}

This study uses a descriptive research method with a quantitative approach to causality. The research instrument used was a questionnaire with a 5-point Likert scale and distributed to members of the police who served at the Yapen Islands Police. The sampling technique used the Slovin formula and simple random sampling so that 167 respondents were 
obtained. The independent variables in this study are the competence of human resources (HR) (X1) and organizational climate (X2), the mediating variable is work motivation (Z), and the dependent variable is job satisfaction $(\mathrm{Y})$.

The validity and reliability tests were conducted first to test the validity and reliability of the questionnaire. Furthermore, the classical assumption test is carried out which consists of the normality test, multicollinearity test, and heteroscedasticity test. After fulfilling the classical assumption test, then the hypothesis test is carried out using the path analysis method. Regression was carried out twice. The first regression was to determine the direct effect of HR competence and organizational climate on work motivation, while the second regression was conducted to determine the direct effect of HR competence, organizational climate, and work motivation on job satisfaction. Furthermore, the Sobel test was carried out to determine the indirect effect of HR competence and organizational climate on job satisfaction mediated by work motivation.

\section{Discussion}

Descriptive analysis in this study was conducted to explain the state of the characteristics of the respondents and the research variables in accordance with the respondents' answers. In this analysis it can be seen the characteristics of the respondents and the answers of each respondent in response to the statements in the research questionnaire. The characteristics of the respondents in this study were grouped according to gender, age, education, task force, and rank. A description of the characteristics of the respondent can be explained as follows.

Table 1. Description of Respondent Characteristics

\begin{tabular}{|c|c|c|c|}
\hline Category & $\begin{array}{c}\text { Alternative } \\
\text { Answers }\end{array}$ & $\begin{array}{l}\text { Number of } \\
\text { Respondents }\end{array}$ & $\begin{array}{c}\text { Percent } \\
(\%)\end{array}$ \\
\hline \multirow{2}{*}{ Gender } & Man & 155 & $92,80 \%$ \\
\hline & Women & 12 & $7,20 \%$ \\
\hline \multirow[t]{9}{*}{ Age } & $<20$ Years & 4 & $2,40 \%$ \\
\hline & $21-25$ years & 31 & $18,56 \%$ \\
\hline & 26-30 Years & 26 & $15,57 \%$ \\
\hline & 31-35 Years & 40 & $23,95 \%$ \\
\hline & 36-40 Years & 34 & $20,36 \%$ \\
\hline & 41-45 years & 19 & $11,38 \%$ \\
\hline & 46-50 Years & 6 & $3,59 \%$ \\
\hline & 51-55 Years & 2 & $1,20 \%$ \\
\hline & $>56$ years & 5 & $2,99 \%$ \\
\hline \multirow[t]{3}{*}{ Education } & High school & 143 & $85,63 \%$ \\
\hline & D3 & 1 & $0,60 \%$ \\
\hline & $\mathrm{S} 1$ & 23 & $13,77 \%$ \\
\hline \multirow{4}{*}{ Task force } & Bag Ops & 8 & $4,79 \%$ \\
\hline & Intelligence & 11 & $6,59 \%$ \\
\hline & Samapta & 32 & $19,16 \%$ \\
\hline & POL Air and Air & 7 & $4,19 \%$ \\
\hline
\end{tabular}




\begin{tabular}{llcc}
\hline \multirow{5}{*}{ Siwas } & 2 & $1,20 \%$ \\
\cline { 2 - 3 } & Bag Sumda & 15 & $8,98 \%$ \\
\hline Criminal & 28 & $16,77 \%$ \\
\hline $\begin{array}{l}\text { Detective } \\
\text { Traffic }\end{array}$ & 22 & $13,17 \%$ \\
\hline Tahti & 4 & $2,40 \%$ \\
\hline Si Ti Pol & 2 & $1,20 \%$ \\
\hline Bag Ren & 6 & $3,59 \%$ \\
\hline Drug Detective & 9 & $5,39 \%$ \\
\cline { 2 - 4 } & Bin Mas & 7 & $4,19 \%$ \\
\cline { 2 - 4 } & The Propam & 10 & $5,99 \%$ \\
\cline { 2 - 4 } Rank & Si Um & 4 & $2,40 \%$ \\
\hline & First Officer & 1 & $0,60 \%$ \\
\cline { 2 - 4 } & Intermediate & 12 & $7,19 \%$ \\
\cline { 2 - 4 } & Officer & 154 & $92,22 \%$ \\
\cline { 2 - 4 } & NCO & &
\end{tabular}

Descriptive analysis was then used to determine the tendency of respondents' answers. The HR competency variable (X1) consists of 8 indicators, organizational climate (X2) 14 indicators, work motivation $(\mathrm{Z}) 10$ indicators, and job satisfaction (Y) 8 indicators. Respondents' answers are then categorized by an interval scale calculated from the highest score minus the lowest score divided by five, so that the interval is 0.80 . With an interval of 0.80 , the categorization system is as follows: 1.00-1.80 (very low); 1.81-2.60 (low); 2.61-3.40 (sufficient); 3,41-4,20 (high); and 4.21-5.00 (very high) (Sugiyono, 2013).

Table 2. Distribution of Respondents' Opinions

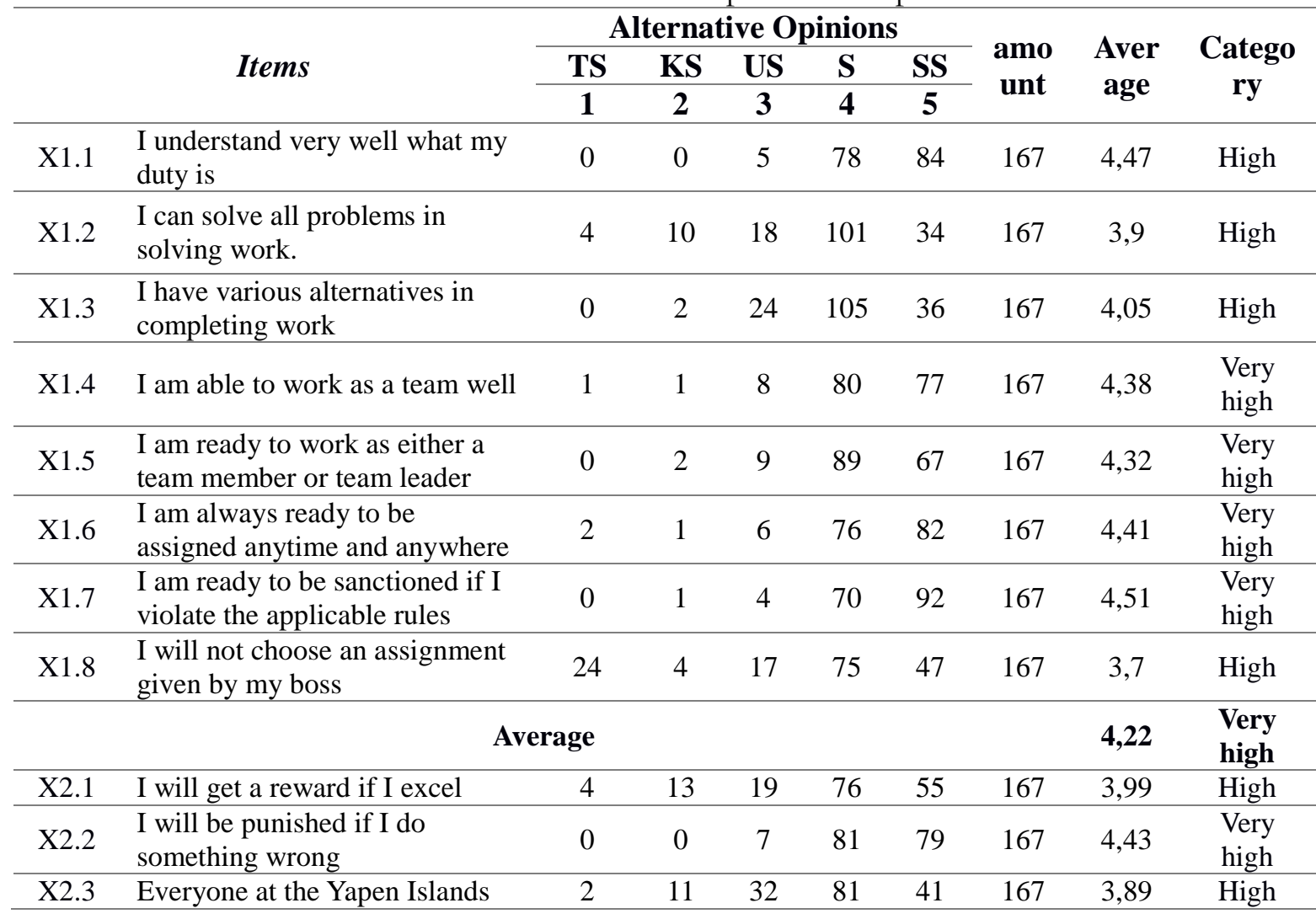




\begin{tabular}{|c|c|c|c|c|c|c|c|c|c|}
\hline & $\begin{array}{l}\text { Police understands their } \\
\text { respective duties and functions }\end{array}$ & & & & & & & & \\
\hline X2.4 & $\begin{array}{l}\text { Everyone is ready to work as a } \\
\text { team }\end{array}$ & 4 & 5 & 22 & 90 & 46 & 167 & 4,01 & High \\
\hline $\mathrm{X} 2.5$ & $\begin{array}{l}\text { Appreciation from the } \\
\text { leadership makes me always } \\
\text { enthusiastic at work }\end{array}$ & 1 & 3 & 14 & 79 & 70 & 167 & 4,28 & $\begin{array}{l}\text { Very } \\
\text { high }\end{array}$ \\
\hline X2.6 & $\begin{array}{l}\text { The leadership always provides } \\
\text { direction and input to all } \\
\text { members }\end{array}$ & 0 & 1 & 5 & 92 & 69 & 167 & 4,37 & $\begin{array}{l}\text { Very } \\
\text { high }\end{array}$ \\
\hline $\mathrm{X} 2.7$ & $\begin{array}{l}\text { Members work according to the } \\
\text { SOP }\end{array}$ & 1 & 2 & 15 & 87 & 62 & 167 & 4,24 & $\begin{array}{l}\text { Very } \\
\text { high }\end{array}$ \\
\hline X2.8 & $\begin{array}{l}\text { The measure of success in the } \\
\text { task is clearly defined }\end{array}$ & 3 & 4 & 22 & 101 & 37 & 167 & 3,99 & High \\
\hline X2.9 & $\begin{array}{l}\text { Interaction between members is } \\
\text { well established }\end{array}$ & 2 & 1 & 26 & 87 & 51 & 167 & 4,1 & High \\
\hline $\mathrm{X} 2.10$ & $\begin{array}{l}\text { All members are ready to lead } \\
\text { and be led in completing tasks }\end{array}$ & 1 & 2 & 21 & 82 & 61 & 167 & 4,2 & High \\
\hline $\mathrm{X} 2.11$ & $\begin{array}{l}\text { All regulations that are enforced } \\
\text { at the central level are well } \\
\text { implemented at the Yapen } \\
\text { Islands Police Headquarters }\end{array}$ & 1 & 5 & 23 & 85 & 53 & 167 & 4,1 & High \\
\hline $\mathrm{X} 2.12$ & $\begin{array}{l}\text { The performance appraisal } \\
\text { system is in accordance with } \\
\text { applicable regulations }\end{array}$ & 0 & 4 & 19 & 103 & 41 & 167 & 4,08 & High \\
\hline $\mathrm{X} 2.13$ & $\begin{array}{l}\text { Each member has clarity in their } \\
\text { duties }\end{array}$ & 2 & 2 & 14 & 110 & 39 & 167 & 4,09 & High \\
\hline $\mathrm{X} 2.14$ & $\begin{array}{l}\text { Not a member who doesn't } \\
\text { know what his job is }\end{array}$ & 4 & 8 & 24 & 91 & 40 & 167 & 3,93 & High \\
\hline \multicolumn{8}{|c|}{ Average } & 4,12 & High \\
\hline Z.1 & $\begin{array}{l}\text { I work according to the ability } \\
\text { that I have }\end{array}$ & 0 & 1 & 10 & 81 & 75 & 167 & 4,4 & $\begin{array}{l}\text { Very } \\
\text { high }\end{array}$ \\
\hline Z.2 & $\begin{array}{l}\text { I am ready to complete the work } \\
\text { that is my responsibility }\end{array}$ & 0 & 0 & 1 & 82 & 84 & 167 & 4,5 & $\begin{array}{l}\text { Very } \\
\text { high }\end{array}$ \\
\hline Z.3 & I like new things at work & 1 & 5 & 19 & 96 & 46 & 167 & 4,1 & High \\
\hline Z.4 & $\begin{array}{l}\text { I will attend training if given the } \\
\text { opportunity }\end{array}$ & 0 & 0 & 8 & 77 & 82 & 167 & 4,4 & $\begin{array}{l}\text { Very } \\
\text { high }\end{array}$ \\
\hline Z.5 & $\begin{array}{l}\text { I will try my hardest to get the } \\
\text { job done }\end{array}$ & 0 & 1 & 5 & 79 & 82 & 167 & 4,4 & $\begin{array}{l}\text { Very } \\
\text { high }\end{array}$ \\
\hline Z.6 & $\begin{array}{l}\text { I am ready to overtime to finish } \\
\text { work }\end{array}$ & 0 & 3 & 15 & 91 & 58 & 167 & 4,2 & High \\
\hline Z.7 & $\begin{array}{l}\text { I will try again when I fail to } \\
\text { complete the assignment }\end{array}$ & 1 & 2 & 9 & 81 & 74 & 167 & 4,3 & $\begin{array}{l}\text { Very } \\
\text { high }\end{array}$ \\
\hline Z.8 & $\begin{array}{l}\text { Giving up on assignments is not } \\
\text { my style }\end{array}$ & 5 & 6 & 9 & 75 & 72 & 167 & 4,2 & High \\
\hline Z.9 & $\begin{array}{l}\text { I want to be promoted } \\
\text { immediately }\end{array}$ & 4 & 8 & 19 & 88 & 48 & 167 & 4 & High \\
\hline Z.10 & $\begin{array}{l}\text { I want to show my colleagues } \\
\text { and leaders that I can excel }\end{array}$ & 4 & 6 & 15 & 89 & 53 & 167 & 4,1 & High \\
\hline \multicolumn{8}{|c|}{ Average } & 4,27 & $\begin{array}{l}\text { Very } \\
\text { high }\end{array}$ \\
\hline Y.1 & $\begin{array}{l}\text { I have the opportunity to excel } \\
\text { at work }\end{array}$ & 0 & 0 & 1 & 67 & 99 & 167 & 4,59 & $\begin{array}{l}\text { Very } \\
\text { high }\end{array}$ \\
\hline Y.2 & $\begin{array}{l}\text { I have a chance to move up the } \\
\text { ranks if it works well }\end{array}$ & 0 & 1 & 6 & 67 & 93 & 167 & 4,51 & $\begin{array}{l}\text { Very } \\
\text { high }\end{array}$ \\
\hline Y.3 & $\begin{array}{l}\text { I receive an award if I have an } \\
\text { achievement at work }\end{array}$ & 0 & 8 & 11 & 80 & 68 & 167 & 4,25 & $\begin{array}{l}\text { Very } \\
\text { high }\end{array}$ \\
\hline Y.4 & All the work I have successfully & 4 & 23 & 34 & 76 & 30 & 167 & 3,63 & High \\
\hline
\end{tabular}




\begin{tabular}{|c|c|c|c|c|c|c|c|c|c|}
\hline & $\begin{array}{l}\text { completed has always received } \\
\text { recognition from my superiors }\end{array}$ & & & & & & & & \\
\hline Y.5 & $\begin{array}{l}\text { There is an incentive that I will } \\
\text { receive if I am able to achieve } \\
\text { work targets }\end{array}$ & 8 & 33 & 29 & 57 & 40 & 167 & 3,53 & High \\
\hline Y.6 & $\begin{array}{l}\text { Working as a police officer is } \\
\text { very satisfying }\end{array}$ & 1 & 2 & 7 & 51 & 106 & 167 & 4,55 & $\begin{array}{l}\text { Very } \\
\text { high }\end{array}$ \\
\hline Y.7 & $\begin{array}{l}\text { Serving at the Polres Yapen } \\
\text { Islands is very enjoyable }\end{array}$ & 1 & 4 & 9 & 55 & 98 & 167 & 4,47 & $\begin{array}{l}\text { Very } \\
\text { high }\end{array}$ \\
\hline Y.8 & $\begin{array}{l}\text { The people at the Yapen Islands } \\
\text { Resort Police supported each } \\
\text { other }\end{array}$ & 1 & 6 & 22 & 81 & 57 & 167 & 4,12 & High \\
\hline \multicolumn{8}{|c|}{ Average } & 4,21 & $\begin{array}{l}\text { Very } \\
\text { high }\end{array}$ \\
\hline
\end{tabular}

Note: $\mathrm{TS}=$ Disagree; $\mathrm{KS}=$ Disagree; $\mathrm{AS}=$ Somewhat Agree; $\mathrm{S}=$ Agree; $\mathrm{SS}=$ Strongly Agree, $\mathrm{X} 1$ = HR Competency; X2 = Organizational Climate; Z = Work Motivation; Y = Job Satisfaction.

The results of the distribution of respondents' opinions in table 2 show that overall respondents considered that HR competence, organizational climate, and work motivation had a strong influence on job satisfaction and relatively agreed with all statements. This can be seen from almost all of the resulting average score values are in the very high range.

Table 3. Validity and Reliability Test Results

\begin{tabular}{|c|c|c|c|c|}
\hline Item & $\begin{array}{c}\mathbf{R} \\
\text { Count }\end{array}$ & Information & $\begin{array}{c}\text { Cronbach's } \\
\text { Alpha }\end{array}$ & Information \\
\hline $\mathrm{X} 1.1$ & 0,620 & Valid & 0,706 & Reliable \\
\hline $\mathrm{X} 1.2$ & 0,543 & Valid & & \\
\hline $\mathrm{X} 1.3$ & 0,570 & Valid & & \\
\hline $\mathrm{X} 1.4$ & 0,622 & Valid & & \\
\hline $\mathrm{X} 1.5$ & 0,703 & Valid & & \\
\hline $\mathrm{X} 1.6$ & 0,545 & Valid & & \\
\hline $\mathrm{X} 1.7$ & 0,646 & Valid & & \\
\hline $\mathrm{X} 1.8$ & 0,585 & Valid & & \\
\hline $\mathrm{X} 2.1$ & 0,555 & Valid & 0,868 & Reliable \\
\hline $\mathrm{X} 2.2$ & 0,336 & Valid & & \\
\hline $\mathrm{X} 2.3$ & 0,717 & Valid & & \\
\hline $\mathrm{X} 2.4$ & 0,627 & Valid & & \\
\hline $\mathrm{X} 2.5$ & 0,347 & Valid & & \\
\hline $\mathrm{X} 2.6$ & 0,628 & Valid & & \\
\hline $\mathrm{X} 2.7$ & 0,682 & Valid & & \\
\hline $\mathrm{X} 2.8$ & 0,495 & Valid & & \\
\hline X2.9 & 0,654 & Valid & & \\
\hline $\mathrm{X} 2.10$ & 0,634 & Valid & & \\
\hline $\mathrm{X} 2.11$ & 0,743 & Valid & & \\
\hline $\mathrm{X} 2.12$ & 0,763 & Valid & & \\
\hline $\mathrm{X} 2.13$ & 0,706 & Valid & & \\
\hline $\mathrm{X} 2.14$ & 0,653 & Valid & & \\
\hline
\end{tabular}




\begin{tabular}{ccccc}
\hline Z.1 & 0,398 & Valid & 0,776 & Reliable \\
\hline Z.2 & 0,571 & Valid & & \\
\hline Z.3 & 0,692 & Valid & & \\
\hline Z.4 & 0,584 & Valid & & \\
\hline Z.5 & 0,665 & Valid & & \\
\hline Z.6 & 0,658 & Valid & & \\
\hline Z.7 & 0,618 & Valid & & \\
\hline Z.8 & 0,614 & Valid & & \\
\hline Z.9 & 0,468 & Valid & & \\
\hline Z.10 & 0,601 & Valid & & \\
\hline Y.1 & 0,423 & Valid & \\
\hline Y.2 & 0,523 & Valid & & \\
\hline Y.3 & 0,551 & Valid & & \\
\hline Y.4 & 0,619 & Valid \\
\hline Y.5 & 0,663 & Valid \\
\hline Y.6 & 0,491 & Valid \\
\hline Y.7 & 0,611 & Valid & & \\
\hline Y.8 & 0,558 & Valid & & \\
\hline
\end{tabular}

The validity test is defined as the extent to which an indicator can reflect the variables. Valid means that the selected instrument can be used to measure what should be measured (Singarimbun \& Effendi, 2016) and to determine the validity is to consult the product moment table based on the significance level of $5 \%$ with $\mathrm{N}=167$ and $\mathrm{p}=0.05$, then we get $\mathrm{r}$ table $=0.151$ (Ghozali, 2011). Table 3 shows that the results of the validity test for all variables can be said to be valid because the statistical $r$ value is greater than the $r$ table value (0.151). In addition to validity, reliability tests were also conducted to measure the level of stability or consistency of measuring instruments (questionnaires). The criterion used to determine the level of reliability is the value (Cronbach's alpha). If the Alpha value is $>$ than 0.6 then the question item is reliable (Sujarweni, 2012). Therefore, all data in this study are reliable because they have a Cronbach's alpha value of more than 0.6.

Table 4. Classical Assumption Test Results

\begin{tabular}{ccccccc}
\hline \multicolumn{2}{c}{ Normality test } & & Multicollinearity Test & \multicolumn{2}{c}{$\begin{array}{c}\text { Heteroscedasticity } \\
\text { Test }\end{array}$} \\
\hline $\begin{array}{c}\text { Kolmogorov } \\
\text { Smirnov }\end{array}$ & $\begin{array}{c}\text { Asymp. } \\
\text { Sig }\end{array}$ & Variable & Tolerance & VIF & Sig value & $\begin{array}{c}\text { Sig } \\
\text { limit }\end{array}$ \\
\hline \multirow{2}{*}{0.066} & & $\mathrm{X} 1$ & 0,687 & 1,457 & 0,537 & 0,05 \\
\cline { 3 - 8 } & 0,075 & $\mathrm{X} 2$ & 0,602 & 1,662 & 0,642 & 0,05 \\
\cline { 3 - 8 } & & $\mathrm{Z}$ & 0,613 & 1,613 & 0,697 & 0,05 \\
\hline
\end{tabular}

The classic assumption test is needed in regression analysis so that the research results do not experience bias or error in estimation. The classical assumption test consists of normality, multicollinearity and heteroscedasticity tests. The normality test was carried out by the Kolmogorov - Smirnov Test. Whether data is normal or not can be seen from the level of significance which must be above 0.05 . The results of the normality test in table 4 show a 
significance value of $0.075>0.05$, so it can be said that the data is normally distributed and meets the normality test.

The multicollinearity test is conducted to determine whether there is a linear relationship between the independent variables. To detect the presence or absence of multicollinearity in the regression model, look at the tolerance value and the VIF (Variance Inflation Factor) value.Based on table 4, the multicoloniearity test results show that the tolerance value is close to 1 and the VIF value is below 10, which means that there is no multicoloniearity between the independent variables in this study. Furthermore, the heteroscedasticity test was carried out with the Glejser test. If the test results show that the independent variable has a significant effect, it is certain that the regression model contains heteroscedasticity problems. The results of the heteroscedasticity test show that all independent variables have a significance value $>0.05$, so it can be said that heteroscedasticity does not occur.

Table 5. First Regression Test Results

\begin{tabular}{|c|c|c|c|c|c|c|}
\hline & \multirow[t]{2}{*}{ Model } & \multicolumn{2}{|c|}{$\begin{array}{c}\text { Unstandardized } \\
\text { Coefficients }\end{array}$} & \multirow{2}{*}{$\begin{array}{c}\text { Standardized } \\
\text { Coefficients } \\
\text { Beta } \\
\end{array}$} & \multirow[t]{2}{*}{$\mathbf{t}$} & \multirow[t]{2}{*}{ Sig. } \\
\hline & & B & Std. Error & & & \\
\hline \multirow[t]{3}{*}{1} & (Constant) & 15,804 & 2,715 & & 5,820 & 000 \\
\hline & HR Competency & ,313 & ,083 & ,266 & 3,762 & 000 \\
\hline & Organizational Climate & ,283 &, 045 & ,444 & 6,268 &, 000 \\
\hline
\end{tabular}

a. Dependent Variable: Work Motivation

The first regression test was conducted to determine the effect of the HR competency variable and organizational climate on work motivation. The test results in table 5 show that HR competency has a positive and significant effect on work motivation seen from the tstatistic value of $3,762>1,974$ (t-table) with a significance of $0,000<0,05$, so it can be concluded that the first hypothesis is accepted. Respondents who are members of the Polres Yapen Islands assess that they have adequate competence in carrying out their jobs. The highest competence is readiness to be sanctioned if they break the rules, being ready to be assigned anytime and anywhere, and being able to work well in a team. This result is in line with previous research conducted by Murgianto et al. (2016), Rijanti et al. (2017), and Solehudin and Yusuf (2018). The higher the competence possessed by the employee, the higher the work motivation.

Organizational climate also has a positive and significant effect on work motivation (tstatistic $=6,209 ; \mathrm{p}<0,05)$ so that the second hypothesis is accepted. This result is in line with previous research conducted by Diputra et al. (2018), Haseeb et al. (2016), and Naseer and Devi (2019). The better the organizational climate, the better the employee's work motivation. A conducive work climate can make organizational members feel comfortable to work, and vice versa. A good organizational climate will make Yapen Islands Police members not have the intention to leave their units because, he feels the working climate can help him in working. The organizational climate that is built in the Yapen Islands Resort Police is carried out by providing rewards for members who excel, responsibility, leadership, standards, team spirit, conformity, and organizational clarity. 
Table 6. Second Regression Test Results

\begin{tabular}{|c|c|c|c|c|c|c|}
\hline & \multirow[t]{2}{*}{ Model } & \multicolumn{2}{|c|}{$\begin{array}{c}\text { Unstandardized } \\
\text { Coefficients }\end{array}$} & \multirow{2}{*}{$\begin{array}{c}\text { Standardized } \\
\text { Coefficients } \\
\text { Beta } \\
\end{array}$} & \multirow[t]{2}{*}{$\mathbf{t}$} & \multirow[t]{2}{*}{ Sig. } \\
\hline & & B & Std. Error & & & \\
\hline \multirow[t]{4}{*}{1} & (Constant) & 8,212 & 2,516 & & 3,264 & 001 \\
\hline & HR Competency & ,063 & ,073 & ,062 & ,867 & ,387 \\
\hline & Organizational Climate & ,233 & ,042 & ,421 & 5,491 & ,000 \\
\hline & Work Motivation & ,230 &, 066 & ,265 & 3,493 & 001 \\
\hline
\end{tabular}

a. Dependent Variable: Work Motivation

Furthermore, the second regression test was carried out to determine the effect of HR competence, organizational climate, and work motivation on job satisfaction. Testing the third hypothesis shows that there is a positive but insignificant influence between HR competencies on job satisfaction (t-statistic $=0,867 ; \mathrm{p}>0,05)$. This result is not in line with previous research conducted by Dharmanegara et al. (2016), Renyut et al. (2017), Sabuhari et al. (2020), and Trivellas et al. (2015). However, it is in line with the research of Adam and Kamase (2019). Whether the employee's competency level is high or not will not affect the level of job satisfaction. When viewed from the results of the descriptive analysis of the respondents' answers, the statement with the lowest average score is related to overcoming problems in solving work and not choosing tasks given by superiors. Two things related to these competencies can be further improved so that the level of competence is higher and ultimately can affect job satisfaction.

The results of testing the fourth hypothesis indicate that organizational climate has a positive and significant effect on job satisfaction (t-statistic $=5,491 ; \mathrm{p}<0.05$ ). These results are in line with research conducted by Sree and Saryavathi (2017), Agbozo et al. (2017) and Castro and Martins (2014). The better the organizational climate, the better job satisfaction will be. From the results of the descriptive analysis, it can be seen that the respondents felt that the organizational climate in the Yapen Kepualauan Police had been well developed. This can be seen from the responses of respondents where one of the good organizational climates is the existence of a reward and punishment system and the establishment of good relationships between members, so as to create a conducive working atmosphere or organizational climate.

Furthermore, the fifth hypothesis which states that there is a positive and significant influence between work motivation and job satisfaction is accepted (t-statistic $=3,493 ; \mathrm{p}$ $<0.05)$. These results are in line with research conducted by Rosalia et al. (2020), Carvalho et al. (2020), and Sohail et al. (2014). The higher the work motivation of the police officers at the Yapen Islands Police, the higher their job satisfaction. Based on the results of the descriptive analysis of the responsive answers, the work motivation of the Yapen Islands Police is in the very high category. High work motivation from the readiness to complete the work for which they are responsible, to work according to their abilities, and trying their hardest to complete the job.

The results of testing all hypotheses in this study are summarized in Figure 2. The relationship between HR competence and job satisfaction is fully mediated by work motivation. The indirect effect is $0,070(0,266 \times 0,265)$. The sobel test results in table 7 show that work motivation can mediate the relationship between HR competence and job satisfaction and is significant with a $95 \%$ confidence interval $(0,116, \sim 0,3582)$ which does not include zero values, therefore the sixth hypothesis is accepted. These results are in line with 
previous research conducted by Josephine and Harjanti (2017), Hasmiah et al. (2020), as well as Utoyo et al. (2019). High HR competence through good work motivation can affect job satisfaction.

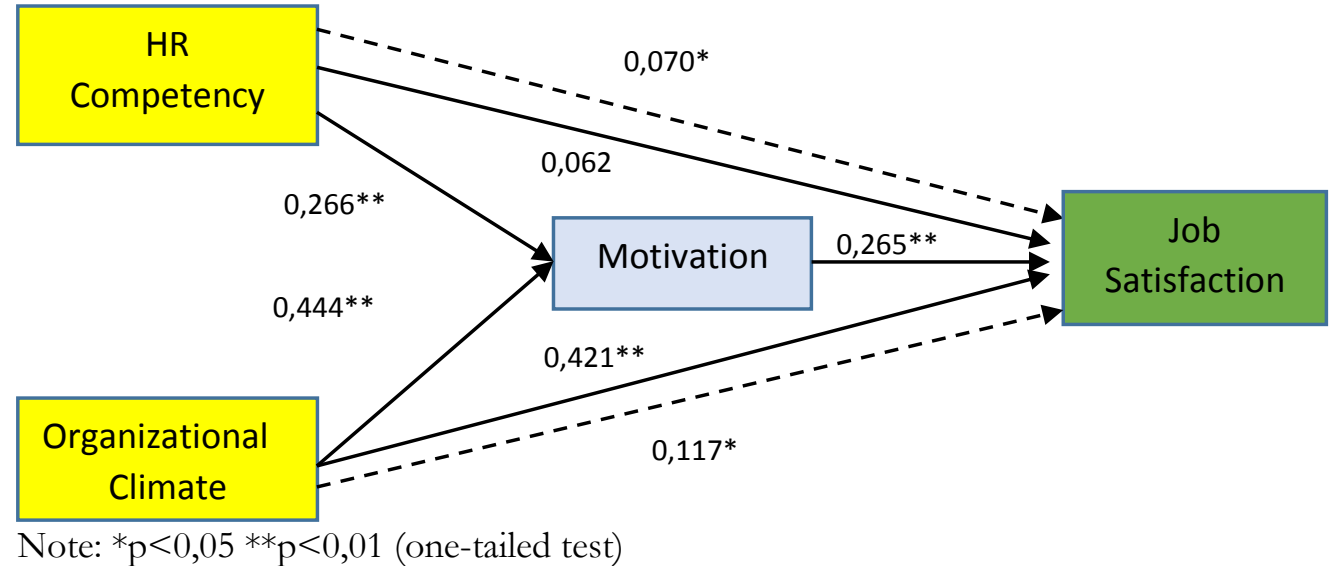

Figure 2. Hypothesis Testing Results

Table 7. Test of Work Motivation Mediators Between Competencies HR-Job Satisfaction

\begin{tabular}{clccc}
\hline \multirow{2}{*}{ Model } & \multicolumn{1}{c}{ Relationship } & $\begin{array}{c}\text { Standardized } \\
\text { Estimate }\end{array}$ & $\begin{array}{c}\text { T } \\
\text { Statistics }\end{array}$ & Sobel test \\
\hline 1 & HR Competencies - Job Satisfaction & $0,4124 * *$ & 5,6830 & Supported \\
\hline 2 & HR Competencies - Work Motivation & $0,5761 * *$ & 7,2213 & \\
\hline & HR Competencies - Job Satisfaction & $0,1882 *$ & 2,4939 & \\
\hline & Work Motivation - Job Satisfaction & $0,3891 * *$ & 6,0607 & \\
\hline
\end{tabular}

Note: $* \mathrm{p}<0,05 * * \mathrm{p}<0,01$ (one-tailed test)

Table 8. Test of Work Motivation Mediators Between Organizational Climate-Job Satisfaction

\begin{tabular}{clccl}
\hline \multirow{2}{*}{ Model } & \multicolumn{1}{c}{ Relationship } & $\begin{array}{c}\text { Standardized } \\
\text { Estimate }\end{array}$ & $\begin{array}{c}\text { T } \\
\text { Statistics }\end{array}$ & Sobel test \\
\hline 1 & Organizational Climate - Job Satisfaction & $0,3354 * *$ & 9,7818 & Supported \\
\hline 2 & Organizational Climate - Work Motivation & $0,3692 * *$ & 9,0991 & \\
\hline & Organizational Climate - Job Satisfaction & $0,2446 * *$ & 6,0648 & \\
\hline & Work Motivation - Job Satisfaction & $0,2462 * *$ & 3,8987 & \\
\hline
\end{tabular}

Note: $* \mathrm{p}<0.05 * * \mathrm{p}<0.01$ (one-tailed test)

Furthermore, the seventh hypothesis which states that work motivation can mediate the relationship between organizational climate and job satisfaction is accepted. The indirect effect is $0.117(0,444 \times 0,265)$, which is greater than the indirect effect of HR competence on job satisfaction $(0,070)$. The sobel test results in Table 8 show that work motivation can mediate the relationship between HR competence and job satisfaction and is significant with a $95 \%$ confidence interval $(0,0342 \sim 0,1507)$ which does not include zero values. The results of this study are in line with the research of Saeed and Nasir (2016) and Gheitani et al. (2019). A conducive organizational climate then supported by good work motivation will be able to increase job satisfaction of the Yapen Islands Police.

\section{Conclusion}

Based on the results of this study, several conclusions can be drawn, namely HR competence and organizational climate have a positive and significant effect on work motivation. The higher the level of human resource competence and the more conducive the 
organizational climate will be, the work motivation of the Yapen Islands Police personnel. Then the organizational climate and work motivation have a positive and significant effect on job satisfaction, while HR competencies do not have a significant effect on job satisfaction. Work motivation can mediate the relationship between HR competencies and job satisfaction and the relationship between organizational climate and job satisfaction.

There are several suggestions and implications obtained from the results of this study. The Yapen Islands Police can maintain an existing organizational climate. However, the organizational climate still needs improvement, especially at the level of understanding of its duties and functions through the supervision program. Meanwhile, HR competencies also still need to be improved because there are still members who tend to choose tasks given by their superiors. Competency improvement programs need to be carried out on an ongoing basis.

Related to work motivation, it appears that members are not motivated by promotion. Therefore, to increase work motivation, leaders do not have to highlight promotions, but can provide rewards such as certificates, incentives and so on. This is because the award from the leader is one of the driving forces for members to be enthusiastic at work.

Then this research respondents are not limited to aspects of rank, age and income. For this reason, further researchers need further analysis regarding aspects of rank, age and income as control variables in analyzing job satisfaction of police officers.

\section{References}

Abuhashesh, M., Al-dmour, R., \& Masa'deh, R. (2019). Factors that affect Employees Job Satisfaction and Performance to Increase Customers ' Satisfactions. Journal of Human Resource Management Research, 1(1), 1-23. https://doi.org/10.5171/2019.354277

Adam, F., \& Kamase, J. (2019). The effect competence and motivation to satisfaction and performance. International Journal of Scientific \& Technology Research, 8(03), 132140.

Ahmad, K. Z. Bin, Jasimuddin, S. M., \& Kee, W. L. (2018). Organizational climate and job satisfaction: do employees' personalities matter? Management Decision.

Amiroso, J., \& Mulyanto. (2015). Influence of Discipline, Working Environment, Culture of Organization and Competence on Workers' Performance through Motivation, Job Satisfaction ( Study in Regional Development Planning Board of Sukoharjo Regency ). European Journal of Business and Management, 7(36), 86-95.

Arafat, M. Y., Warokka, A., Abdullah, H. H., \& Septian, R. R. (2012). The triple bottom line effect on emerging market companies: A test of corporate social responsibility and firm value relationship. Journal of Southeast Asian Research, 2012(2012), 1-15.

Berlian, Z. (2018). Competency Analysis of Job Satisfaction and Organizational Commitment to Lecturers Who Teach at Private Universities in the Area of Southern Sumatra. American Research Journal of Business and Management, 4(1), 1-6.

Carvalho, A. da C., Riana, I. G., \& Soares, A. de C. (2020). Motivation on job satisfaction and employee performance. International Research Journal of Management, IT and Social Sciences, 7(5), 13-23.

Deswarta. (2017). Pengaruh Kompetensi dan Motivasi terhadap Kepuasan Kerja dan Kinerja Dosen. Jurnal Valuta, 3(1), 19-39.

Dharmanegara, I. B. A., Sitiari, N. W., \& Wirayudha, I. (2016). Job competency and work environment: the effect on job satisfaction and job performance among SMEs worker. IOSR Journal of Business and Management (IOSR-JBM), 18(1), 19-26. 
Diputra, D. G. A. S., Agung, A. A., \& Kepramareni, P. (2018). The Influence of Leadership and Organizational Climate of Employee Performance through Motivation as a Mediation Variable. International Journal of Contemporary Research and Review, $9(08$ SE-Management and Economics). https://doi.org/10.15520/ijcrr/2018/9/08/571

Gheitani, A., Imani, S., Seyyedamiri, N., \& Foroudi, P. (2019). Mediating effect of intrinsic motivation on the relationship between Islamic work ethic, job satisfaction, and organizational commitment in banking sector. International Journal of Islamic and Middle Eastern Finance and Management.

Ghozali, I. (2011). Aplikasi Analisis Multivariate dengan Program IBM SPPS 20. UNDIP.

Goldsmith, A. (2005). Police reform and the problem of trust. Theoretical criminology, 9(4), $443-470$.

Hasmiah, H., Echdar, S., \& Maryadi, M. (2020). Pengaruh Kompetensi dan Kompensasi terhadap Kepuasan Pegawai melalui Motivasi Kerja pada Kantor Kecamatan Ma'rang Kabupaten Pangkajene dan Kepulauan. Jurnal Magister Manajemen Nobel Indonesia, 1(2), 233-242.

Josephine, A., \& Harjanti, D. (2017). Pengaruh Lingkungan Kerja Terhadap Kinerja Karyawan Pada Bagian Produksi Melalui Motivasi Kerja Sebagai Variabel Intervening Pada PT . Trio Corporate Plastic (Tricopla ). Jurnal Agora, 5(3), 1-8.

Masum, A. K. M., Azad, A. K., \& Beh, L. (2015). Determinants of Academics ' Job Satisfaction: Empirical Evidence from Private Universities in Bangladesh. Journal PLoS ONE, 10(2), 1-15. https://doi.org/10.1371/journal.pone.0117834

Morris, A., \& Bloom, J. R. (2002). Contextual factors affecting job satisfaction and organizational commitment in community mental health centers undergoing system changes in the financing of care. Mental health services research, 4(2), 71-83.

Mueller, C., \& Kim, S.-W. (2008). The contented female worker: still a paradox? Emerald Group Publishing Limited.

Murgianto, M., Suhermin, S., \& Sulasmi, S. (2016). The Effects of Commitment, Competence, Work Satisfaction on Motivation, and Performance of Employees at Integrated Service Office of East Java. International Journal of Advanced Research, 3, 378-396.

Naseer, A., \& Devi, M. (2019). Effect of Organisational Climate on Employees Motivation in University Libraries in Kerala: An Investigative Study. Indian Journal of Information Sources and Services, 9(1), 71-75.

Pintrich, P. R., \& Schunk, D. H. (2002). Motivation in Education: Theory, Research, and Applications (2 ed.). Prentice-Hall.

Pratomo, W. A., \& Warokka, A. (2013). The Linkages of Financial Liberalization and Currency Stability: What do we learn from Pre and Post Asian Financial Crisis?. Journal of Economics Studies and Research, 2013, 1.

Rante, A., \& Warokka, A. (2016). Leadership style, decentralisation and managerial performance: Does the management accounting system mediate the relationship?. Journal for Global Business Advancement, 9(1), 79-89.

Renyut, B. C., Modding, H. B., Bima, J., \& Sukmawati, S. (2017). The effect of organizational commitment, competence on Job satisfaction and employees performance in Maluku Governor' s Office. IOSR Journal of Business and Management, 19(11), 18-29. https://doi.org/10.9790/487X-1911031829

Rijanti, T., Priyono, B. S., \& Nugroho, H. P. (2017). The influence of competence and job characteristics on performance with motivation as mediating variable at regional finance agency of tegal city. The Sixth International Conference on Entrepreneurship and Business Management,(Icebm), 412-419.

Rosalia, P. D., Mintarti, S., \& Heksarini, A. (2020). The Effect of Compensation and Motivation on Job Satisfaction and Employee Performance at SMK Medika Samarinda. 
Saban, D., Basalamah, S., Gani, A., \& Rahman, Z. (2020). Impact of Islamic work ethics, competencies, compensation, work culture on job satisfaction and employee performance: the case of four star hotels. European Journal of Business and Management Research, 5(1).

Sabuhari, R., Sudiro, A., Irawanto, D., \& Rahayu, M. (2020). The effects of human resource flexibility, employee competency, organizational culture adaptation and job satisfaction on employee performance. Management Science Letters, 10(8), 1775-1786.

Saeed, H. M. I., \& Nasir, N. (2016). Work Environment on Job Satisfaction with mediating effect of Motivation among School Teachers in Lahore, Pakistan. Journal of Management Engineering and Information Technology (JMEIT), 3(6), 1-5.

Saleem, R., Mahmood, A., \& Mahmood, A. (2010). Effect of Work Motivation on Job Satisfaction in Mobile Telecommunication Service Organizations of Pakistan. International Journal of Business and Management Vol., 5(11), 213-222.

Singarimbun, M., \& Effendi, S. (2016). Metode Penelitian Survai. LP3S.

Sohail, B. A., Safdar, R., Saleem, S., Ansar, S., \& Azeem, M. (2014). Effect of Work Motivation and Organizational Commitment on Job Satisfaction: (A Case of Education Industry in Pakistan). Global Journal of Management and Business Research: A Administration and Management, 14(6), 40-46.

Solehudin, \& Yusuf, A. (2018). Pengaruh Budaya Organisasi dan Kompetensi Terhadao Motivasi Kerja. Value Journal of Management and Business, 3(1), 380-391.

Sugiyono. (2013). Metode Penelitian Kuantitatif, Kualitatif dan R\&D. Alfabeta.CV.

Sujarweni, V. W. (2012). Belajar Mudah SPSS untuk Penelitian: Skripsi, Tesis, Disertasi \& Umum. Global Media Informasi.

Syamsir, S. (2020). Competence, Job Satisfaction, Work Motivation, and Job Performance of The Village ("Nagari") Masters in Managing E-Village Finance. International Journal of Advanced Science and Technology, 29(8), 1337-1350.

Tomaževič, N., Seljak, Janko, Aristovnik, \& Aleksander. (2015). Munich Personal RePEc Archive Factors Influencing Employee Satisfaction in the Police Service: The Case of Slovenia. MPRA: Munich Personal RePEc Archive, 62037.

Trivellas, P., Akrivouli, Z., Tsifora, E., \& Tsoutsa, P. (2015). The impact of knowledge sharing culture on job satisfaction in accounting firms. The mediating effect of general competencies. Procedia Economics and Finance, 19, 238-247.

Utoyo, B., Yohana, C., \& Fakultas, M. (2019). The Effect of Competence and Organizational Culture, on Performance of Employees with Work Motivation as a Mediation Variable.

Vidya, N., \& Kotian, S. (2014). Job Satisfaction Among Women Police Personals - A Literature Review. Indian Journal of Applied Research, 4(12), 218-220. 